\title{
Efektivitas Ventilator dalam Proses End of Life dan Tinjauannya Menurut Pandangan Islam
}

\section{The Effectiveness of Ventilators in The End of Life Process and Its Islamic Perspective}

\author{
Yulya Mauliddina ${ }^{1}$, Ferryal Basbeth ${ }^{2}$, M Arsyad $^{3}$ \\ ${ }^{1}$ Student, Faculty of Medicine, YARSI University, Jakarta \\ ${ }^{2}$ Lecturer, Department of Forensic, Faculty of Medicine, YARSI University, Jakarta \\ ${ }^{3}$ Lecturer, Department of Islamic Religion, YARSI University, Jakarta \\ Jalan Letjen Suprapto, Cempaka Putih, Jakarta 10510 \\ Email:yulya.mauliddina@gmail.com; basbethf@gmail.com; muhammad.arsyad@yarsi.ac.id
}

KATA KUNCI Ventilator mekanik, End of life, Perawatan pasien kritis

ABSTRAK

KEYWORDS

ABSTRACAT
Latar Belakang: Ventilator mekanik merupakan alat yang digunakan untuk membantu fungsi pernapasan. Penggunaannya diindikasikan untuk pasien dengan hipoksemia, hiperkapnia berat dan gagal napas. Ventilator mekanik merupakan salah satu aspek yang penting dan banyak digunakan bagi perawatan pasien yang kritis di Intensive Care Unit (ICU). Metode: Penelitian dilakukan dengan teknik pengambilan sampel secara non-probability. Teknik non-probability sampling ditetapkan dengan cara purposive yaitu menetapkan kriteria terlebih dahulu lalu sampel yang di ambil sesuai dengan kriteria yang telah ditetapkan. Hasil: Sebanyak 98 rekam medik yang di ambil dari ICU RS. Juwita Bekasi dari tahun 2013-2017 menunjukan bahwa 3 pasien diantaranya menunjukkan hasil yang efektif teradap pemasangan ventilator dan 95 pasien menunjukkan hasil yang tidak efektif. Simpulan: Berdasarkan rekam medik terkait pemasangan ventilator di ICU RS. Juwita Bekasi dari tahun 2013-2017 menggambarka hasil yang tidak efektif karena tingkat efektifitas hanya $1 \%$.

\section{Mechanical ventilator, End of life, Care for critical patients}

Background: A mechanical ventilator is a device used to help with respiratory function. Its use is indicated for patients with hypoxemia, severe hypercapnia and respiratory failure. Mechanical ventilator is one of the important and widely used aspects for critical patient care in the Intensive Care Unit (ICU). Methods: This research was conducted with non-probability sampling techniques. Non-probability sampling techniques was determined by purposive method, which is to determine the criteria first, then the samples are taken according to predetermined criteria. Results: As much as 98 medical records taken from the Juwita Bekasi Hospital ICU from 2013-2017 showed that 3 
patients showed effective results for ventilator installation and 95 patients showed ineffective results. Conclusion: Based on medical record in Juwita Bekasi Hospital from 2013 to 2017, The mechanical ventilation installation was not effective and only has $1 \%$ effectivity.

\section{PENDAHULUAN}

Ventilator mekanik merupakan alat yang digunakan untuk membantu fungsi pernapasan. Penggunaannya di indikasikan untuk pasien dengan hipoksemia, hiperkapnia berat dan gagal napas. Ventilator mekanik merupakan salah satu aspek yang penting dan banyak digunakan bagi perawatan pasien yang kritis di Intensive Care Unit(ICU), dengan penggunaan di Amerika Serikat mencapai 1,5 juta per tahun.

Pasien yang dirawat di ICU berisiko tinggi terkena infeksi nosokomial. Infeksi nosokomial yang cukup sering diderita pasien adalah pneumonia, yang terjadi 48 jam atau lebih setelah ventilator mekanik diberikan. $87 \%$ kejadian pneumonia di ICU terkait dengan penggunaan dan asuhan keperawatan ventilator mekanik yang tidak tepat sehingga menimbulkan kolonisasi kuman di orofaring yang berisiko terjadinya pneumonia terkait ventilator/Ventilator Associated Pneumonia (VAP).

Penyapihan ventilator mekanik sebaiknya segera dilakukan jika masalah gagal nafas sudah tertangani. Hal ini didasarkan pada alasan bahwa pemasangan ventilator mekanik yang berkepanjangan akan memberikan dampak negatif diantaranya terjadinya Ventilator Associated Pneumonia (VAP), cidera paru, infeksi nosokomial, hiponutrisi, sepsis, kematian, hari perawatan meningkat, dan peningkatan biaya rumah sakit (Funk, 2010; Hsu et al., 2013).
Berangkat dari hal tersebut, maka penelitian ini penting dilakukan untuk mengetahui bagaimana efektivitas pemakaian ventilator dalam proses End of Life pada pasien.

Al-Qur'an menunjukkan bahwa setiap makhluk yang bernyawa (ruh) pasti mati, bahkan alam dunia pun akan diakhiri dengan mati (kiamat). Oleh karena itu, kematian adalah suatu kepastian, dan tiada satu pun yang dapat melarikan diri daripadanya dan bahkan mati yang akan mendatanginya. Di sini Al-Qur'an justru mensifatkan mati sebagai sunnah Allah swt yang umum bagi segala kejadian. Sebagaimana yang telah terdapat dalam Al-Qur'an.

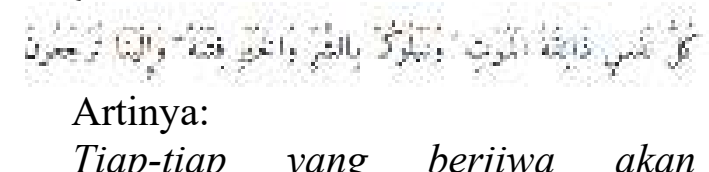
merasakan mati. Kami akan menguji kamu dengan keburukan dan kebaikan sebagai cobaan (yang sebenar-benarnya). Dan hanya kepada Kamilah kamu dikembalikan (QS Al-Anbya (21): 35).

Sesuatu yang bernyawa tidak akan mati melainkan dengan izin Allah, sebagai ketetapan yang telah ditentukan waktunya”. (QS Ali Imran: 145). Setiap hamba Allah akan meninggal dengan sepengetahuan dan atas izin Nya, tidak ada yang mampu menentukan kapan dan cara kematiannya sendiri. Sebab merupakan sebuah ketetapan yang hanya diketahui oleh Allah sebagai penciptaNYA.

Penggunaan alat "penyambung nyawa" berupa ventilator atau alat bantu pernafasan bagi pasien yang berada dalam 
kondisi koma. Namun, forum yang digelar di Pondok Pesantren Al-Itqon itu bukan membahas hukum boleh atau tidaknya penggunaan alat tersebut dari sudut hukum Islam, karena mayoritas (jumhur) ulama sudah jelas memperbolehkan. Sementara pencabutan alat bantu pernafasan diperbolehkan jika diyakini bahwa pasien pada hakikatnya telah meninggal dunia berdasar keterangan resmi dokter ahli yang menangani dan pasien yang sudah lama berobat di rumah sakit dengan alasan tidak kunjung sembuh dan menelan biaya yang sangat mahal, forum bahtsul masail pun tidak menilainya sebagai praktik euthanasia (Nahdlatul Ulama, 2010).

\section{METODOLOGI}

Penelitian ini merupakan penelitian kualitatif. Bertujuan untuk mengetahui efektivitas penggunaan ventilator dalam proses End of Life yang dilakukan di Rumah Sakit Juwita Bekasi. Populasi penelitian ini diambil dari data rekam medik pasien remaja (10-19 tahun), dewasa muda (20-25 tahun) dewasa penuh (25-65 tahun dari tahun 2013-2017. Pengambilan sampel secara nonprobability. Teknik non-probability sampling akan ditetapkan dengan cara purposive yaitu menetapkan kriteria terlebih dahulu lalu sampel yang di ambil sesuai dengan kriteria yang telah ditetapkan. Penetapan besar sampel dilakukan dengan mengevaluasi data kualitatif berdasarkan rekam medik tahun 2013-2017 di Rumah Sakit Juwita Bekasi.

\section{ISI}

Hasil data yang diperoleh dari rekam medik Rumah Sakit Juwita Bekasi mengenai data pasien yang menggunakan ventilator di ICU dari tahun 2013- 2017. Hasil penelitian ini didapatkan dengan dari pengambilan data sekunder. Penetapan besar sampel dilakukan dengan mengevaluasi data kualitatif berdasarkan rekam medik tahun 2013-2017 di Rumah Sakit Juwita Bekasi. Penelitian ini menggunakan teknik pengambilan sampel secara non-probability. Teknik nonprobability sampling akan ditetapkan dengan cara purposive yaitu menetapkan kriteria terlebih dahulu lalu sampel yang diambil sesuai dengan kriteria yang telah ditetapkan.

Penelitian ini dilakukan dengan pengambilan data rekam medik di ICU RS. Juwita Bekasi tahun 2013-2017, dan dilakukan selama 26 hari yaitu dimulai dari tanggal 12 Februari sampai 15 Maret 2019.

Berikut ini merupakan data rekam medik yang di peroleh selama dilakukannya penelitian.

Table 1. Efektivitas ventilator di ICU RS. Juwita Bekasi

\begin{tabular}{|c|c|c|}
\hline Umur & Diagnosa & $\begin{array}{c}\text { Efektivitas } \\
\text { Ventilator }\end{array}$ \\
\hline 54 & Meningitis & Tidak \\
\hline 43 & Meningitis & Tidak \\
\hline 60 & Sequel stroke + Geriatric Problem & Tidak \\
\hline
\end{tabular}


48

55

58

60

56

67

59

55

60

70

54

41

65

68

51

40

40

58

60

55

55

60

56

65

43
Infark Miokard

Infark Miokard

Infark Miokard

Infark Miokard

Infark Miokard

Infark Miokard

Infark Miokard

CKF

CKF

CKF

CKF

CKF

CKF

CKF

CKF + Edema Paru

Bronkopneumoni

Bronkopneumoni

Bronkopneumoni

CKD ON HD + Edema Paru

CKD ON HD + Anemia Mikrositik Hipokrom

Syok Kardiogenik

Syok Kardiogenik

Syok Kardiogenik

Bronkiektasis

Bronkiektasis

PPOK

PPOK

PPOK

PPOK

PPOK
Tidak

Tidak

Tidak

Tidak

Tidak

Tidak

Tidak

Tidak

Tidak

Tidak

Tidak

Tidak

Tidak

Tidak

Tidak

Tidak

Tidak

Tidak

Tidak

Tidak

Tidak

Tidak

Tidak

Tidak

Tidak

Tidak

Tidak

Tidak

Tidak

Efektif 


\begin{tabular}{|c|c|c|}
\hline 30 & Pneumonia & Efektif \\
\hline 46 & Pneumonia & Tidak \\
\hline 65 & Stroke & Tidak \\
\hline 73 & Stroke & Tidak \\
\hline 59 & Stroke & Tidak \\
\hline 70 & Stroke & Tidak \\
\hline 21 & Meningoensefalitis & Tidak \\
\hline 43 & Meningoensefalitis & Tidak \\
\hline 46 & Meningoensefalitis & Tidak \\
\hline 65 & Gagal Jantung & Tidak \\
\hline 40 & Gagal Jantung & Tidak \\
\hline 65 & Gagal Jantung & Tidak \\
\hline 68 & Gagal Jantung & Tidak \\
\hline 59 & Gagal Jantung & Tidak \\
\hline 51 & Gagal Jantung & Tidak \\
\hline 40 & Angina pektoris & Tidak \\
\hline 30 & Angina pectoris & Tidak \\
\hline 43 & Angina pectoris & Tidak \\
\hline 26 & Angina pectoris & Tidak \\
\hline 41 & Angina pektoris & Tidak \\
\hline 39 & Angina pectoris & Tidak \\
\hline 55 & Angina pectoris & Tidak \\
\hline 48 & Ca Abdomen & Tidak \\
\hline 53 & Ca Abdomen & Tidak \\
\hline 39 & Ca Abdomen & Tidak \\
\hline 40 & Ca Paru & Tidak \\
\hline 55 & Ca Paru & Tidak \\
\hline 48 & Ca Paru & Tidak \\
\hline 58 & Ca Paru & Tidak \\
\hline
\end{tabular}


Tidak

Tidak

Subdural Hematoma

Tidak

Tidak

Subdural Hematoma

Tidak

Asiksia

Tidak

Asiksia

Tidak

Asiksia

Tidak

Asiksia

Tidak

Asiksia

Tidak

66

Asiksia

Tidak

Asiksia

Tidak

Asiksia

Tidak

Asiksia

Efektif

38

Emboli Paru

Tidak

Emboli Paru

Tidak

Emboli Paru

Tidak

Emboli Paru

Tidak

Emboli Jantung

Tidak

Emboli Jantung

Tidak

Emboli Jantung

Tidak

60

Emboli Jantung

Tidak

Emboli Jantung

Tidak

40

Emboli Jantung

Tidak

Cidera Kepala Berat

Tidak 
Dari Tabel 1. didapatkan 98 pasien dengan berbagai macam diagnosis. Terdapat pasien berumur 43 tahun dengan diagnosis PPOK, 30 tahun dengan diagnosis pneumoni, dan pasien umur 19 tahun dengan diagnosis asfiksia efektif dengan penggunaan ventilator.

Menurut data pada Tabel 1, 3 dari 98 pasien di RS. Juwita Bekasi efek dengan penggunaan ventilator yaitu dengan diagnosis PPOK, pneumoni, dan asfiksia. Dari data tersebut didapatkan pula informasi pasien yang tidak menunjukan efektivitas dalam penggunaan ventilator. Dari 95 pasien yang tidak efektif dengan penggunaan ventilator diagnosis terbayak berupa cidera kepala berat sebanyak 12 kasus. Dan disusul dengan diagnosis lainnya berupa asfiksia 9 kasus, gagal ginjal kronik 8 kasus, infark miokard 7 kasus, angina pektoris 7 kasus, gagal jantung 6 kasus, emboli jantung 6 kasus, PPOK 5 kasus, emboli paru 4 kasus. Ada pula beberapa diagnosis diantaranya bronkopneumoni, meningitis, syok kardiogenik, bronkiektasis, pneumonia, stoke, meningoensefalitis, ca abdomen, ca paru, penyakit jantung reumatik, dan subdural hematoma. Hal ini sesuai dengan penelitian di India mendapati tingkat mortalitas pasien yang menggunakan VM sebesar 71,4\% (Sudarsanam, 2005).
Penelitian lain menyebutkan umur dan derajat keparahan penyakit merupakan dua factor utama yang berperan dalam hasil rawat pasien usia lanjut di ICU. Usia diperkirakan sangat berperan dalam kuat dengan hasil rawat pasien di ICU. Akan tetapi hubungan ini dapat dipengaruhi oleh gangguan fisiologi akut, perubahan seeiring usia, dan perbedaan penangan di masing-masing ICU (Boumendil, 2004).

Lama perawatan pasien yang panjang menunjukan penyakit cenderung lebih buruk atau sudah terdapat komplikasi atau memiliki penyakit penyerta lainnya. Selain itu lamanya perawatan di ICU dapat meningkatkan jumlah biaya yang harus dikeluarkan, faktor biaya ini menjadi salah satu faktor nonmedis yang turut berperan dalam penanganan pasien di ICU. Hal ini terutama pada pasien yang memiliki lama rawat dari tujuh hari sehingga biaya perawatan jauh lebih besar dan lebih memutuskan untuk pulang paksa. Tingginya biaya ICU memang menjadi salah satu kendala di negara berkembang seperti Indonesia. Pasien dengan lama rawat yang singkat dapat diindikasikan beberpa faktor, yakni memang keadaan pasien yang dapat membaik dalam 24 jam atau justru sebaliknya meninggal dan faktor biaya yang menyebabkan pasien 
harus pulang paksa atau memburuk (Boumendil, 2004).

\section{PENUTUP}

Berdasarkan hasil penelitian, dapat disimpulkan bahwa penggunaan ventilator pada RS. Juwita Bekasi memang terbukti efektif, namun angka efektivitas penggunaan ventilator ini masih cukup rendah karena selain dapat membantu pasien dalam proses pernafasan penggunaan ventilator ini juga menyebabkan beberapa dampak yang tidak diinginkan salah satunya terjadi infeksi lain dalam proses perawatan tersebut.

Diharapkan ada penelitian lebih lanjut mengenai efektivitas penggunaan ventilator dalam proses End of Life dan diharapkan setiap dokter benar-benar memberikan pemahaman dan penjelasan yang terbaik untuk keluarga pasien dalam rangka perawatan pasien dalam proses End of Life.

\section{DAFTAR PUSTAKA}

Al- Qur'an dan Terjemahnya, Departemen Agama Republik Indonesia, Jakarta. Adhista. Bona, Rumende. Cleopas. M, Pitoyo. Ceva. W. 2014. FaktorFaktor Prediktor Mortalitas pada Pasien dengan Ventilator Mekanik di Rumah Sakit Cipto Mangunkusumo, Jakarta. Diakses : FaktorFaktor\%20Prediktor\%20Mor talitas\%20pada\%20Pasien\%20deng an $\% 20$ Ventilator $\% 20$ Mekanik $\% 20$ di\%20Rumah\%20Sakit \%20Cipto\% 20Mangunkusumo, $\%$ 20Jakarta.pdf (12 Oktober 2018)
Bagus,Ida.W.P， Nengah I.K.A. 2018. Penyapihan Ventilasi Mekanik. Diakses:

http://download.portalgaruda.org/ar ticle.php?article $=151062 \& \mathrm{val}=970$

$\&$ title $=$ SEPARATION $\% 200 F \% 20$ MECHANICAL \%20VENTILATI ON (12 Oktober 2018)

Latif, Umar. 2016. Konsep mati dan hidup dalam islam(pemahaman mati berdasarkan konsep eskatologis). http://jurnal.arraniry.ac.id/index.php/bayan/article /download/875/689(diakses $\quad 27$ Maret 2019)

Purwoko, Krisman. 2010. NU Bahas Hukum Alat "Penyambung Nyawa". https://republika.co.id/berita/duniaislam/islamnusantara/10/07/09/123924-nubahas-hukum-alat-penyambungnyawa-(diakses pada 27 Maret 2019)

Romadhon, Alam. 2013. Pola Pikir Etika dalam Praktik Kedokteran. Diakses :

http://www.kalbemed.com/Portals/ 6/25 206OpiniPola\%20Pikir\%20Et ika\%20dalam\%20Praktik\%20Kedo kteran.pdf (12 Oktober 2018)

Undang-undang Kemenkes RI no. 29 tahun 2004 tentang Praktik Kedokteran.

Undang-undang Republik Indonesia No.36 Th. 2009 tentang definisi Kematian.

Undang - undang tahun 1945 pasal 28 A Suryadi, Taufik. 2017. Aspek BioetikaMedikolegal Penundaan dan Penghentian Terapi Bantuan Hidup pada Perawatan Kritis. Diakses: (12 Oktober 2018)

Zuhroni. 2010. Pandangan Islam Terhadap Masalah Kedokteran dan Kesehatan. 